\title{
Multi-Elemental Contamination and Historic Record in Sediments from the Santos-Cubatão Estuarine System, Brazil
}

\author{
Wanilson Luiz-Silva, ${ }^{* a}$ Wilson Machado ${ }^{b}$ and Rosa H. R. Matos ${ }^{c}$ \\ ${ }^{a}$ Instituto de Geociências, Universidade Estadual de Campinas, CP 6152, 13083-970 Campinas-SP, Brazil \\ ${ }^{b}$ Departamento de Geoquímica, Universidade Federal Fluminense, 24020-150 Niterói-RJ, Brazil \\ ${ }^{c}$ R. Aglair Buratto Villas Boas, 508, 13087-725 Campinas-SP, Brazil
}

\begin{abstract}
Este trabalho registra pela primeira vez o histórico da contaminação e as fontes de 38 elementos em sedimentos do sistema estuarino de Santos-Cubatão (SE do Brasil), em uma das áreas mais industrializadas da América Latina. A composição de um testemunho de $260 \mathrm{~cm}$ de profundidade do estuário do rio Morrão foi determinada por ICP-MS e avaliada por meio de fatores de enriquecimento, análise de componentes principais, matrizes de correlação e assinaturas geoquímicas. Elementos contaminantes como Cr, Mn, Ni, Zn, Ga, Ag, Cd, Sn, Sb, Pb e Bi foram associados ao $\mathrm{Fe}$, derivados de atividades siderúrgicas, enquanto $\mathrm{Be}, \mathrm{Ca}, \mathrm{Sc}, \mathrm{Co}, \mathrm{Cu}, \mathrm{Sr}, \mathrm{Y}, \mathrm{Zr}$, $\mathrm{Nb}, \mathrm{Hf}$, Ta, Th e U estiveram associados ao $\mathrm{P}$, relacionados ao processo produtivo de fertilizantes. Uma sobreposição da distribuição do Fe sedimentar e produção local de aço indicaram que o Fe é um marcador confiável do histórico da contaminação, permitindo a estimativa de taxas de sedimentação para 45 anos de atividades industriais.
\end{abstract}

This paper records for the first time the contamination history and identifies the sources of 38 elements in sediments from the Santos-Cubatão Estuarine System (SE Brazil), at one of the most industrialized areas in Latin America. The compositions of samples from a $260 \mathrm{~cm}$ long sediment core collected in the Morrão River estuary were determined by ICP-MS. Enrichment factors, principal component analysis, correlation matrixes, and the characterization of geochemical signatures permitted a consistent data evaluation. Contaminant elements such as $\mathrm{Cr}, \mathrm{Mn}, \mathrm{Ni}, \mathrm{Zn}, \mathrm{Ga}$, $\mathrm{Ag}, \mathrm{Cd}, \mathrm{Sn}, \mathrm{Sb}, \mathrm{Pb}$, and $\mathrm{Bi}$ were associated with steel plant-derived Fe concentrations, while Be, $\mathrm{Ca}, \mathrm{Sc}, \mathrm{Co}, \mathrm{Cu}, \mathrm{Sr}, \mathrm{Y}, \mathrm{Zr}, \mathrm{Nb}, \mathrm{Hf}, \mathrm{Ta}$, Th, and $\mathrm{U}$ were associated with fertilizer industry-derived $\mathrm{P}$ concentrations. An overlap of sedimentary Fe distribution and local steel plant production indicated that $\mathrm{Fe}$ is a reliable marker of the contamination history, allowing the estimation of sedimentation rates over a period of 45 years of industrial activities.

Keywords: intertidal sediments, pollution, trace-elements, contamination source, industrial contamination

\section{Introduction}

Human activities in coastal areas have accelerated the input of chemical contaminants to coastal ecosystems, implying in environmental concerns at local, regional and global scales. Despite the implementation of contamination control policies, anomalously high levels of multiple contaminants have still been recorded in many coastal sediments, as observed in the Santos-Cubatão Estuarine System in São Paulo State, Southeastern Brazil. ${ }^{1}$ This setting is historically, economically and environmentally important

*e-mail: wanilson@ige.unicamp.br at a regional scale. Human activities in the estuary started in the beginning of the $16^{\text {th }}$ century, just after the arrival of the first Portuguese explorers in Brazil. The process of colonization began in São Vicente City, the oldest Brazilian colonization settlement, and soon afterwards in Santos City, the home of the largest harbor in Latin America today.

The riverine and estuarine systems in this area have been seriously contaminated since the 1950s, when the activities of the largest industrial complex in Latin America started around Cubatão City. ${ }^{2}$ In the 1980 s, due to uncontrolled emissions of solid, liquid and gaseous contaminants from chemical, petrochemical, steel plant, and fertilizers industries (just to mention the most significant), Cubatão 
City was considered one of the most contaminated areas in the world. Since 1984, a governmental pollution control program has been conduced. ${ }^{3}$

Previous studies have shown that sediments, water, air, and biota from the Santos-Cubatão Estuarine System (as well as the adjacent Santos Bay) are contaminated by emissions of industrial and domestic wastes. ${ }^{2,4-6}$ The contaminants include hazardous nutrients, trace-metals, polycyclic aromatic hydrocarbons, and radionuclides. ${ }^{7-11}$

Despite the effluent emission control by São Paulo State Environmental Protection Agency (CETESB), tracemetal levels in sediments are high at present in the SantosCubatão Estuarine System, since the sediments act as sinks for metal contaminants. ${ }^{1}$ So, high enrichment factors (EF) of metals in surficial fine-grained sediments in relation to pre-industrial background levels have been recorded for $\mathrm{Hg}$ (maximum EF = 49), Mn (48), La (29), Ca (20), Sr (19), $\mathrm{Cd}$ (18), $\mathrm{Zn}$ (16), $\mathrm{Pb}$ (12), $\mathrm{Cu}$ (11), $\mathrm{Cr}$ (8.4), $\mathrm{Fe}$ (> 6.8), Nb (6.9), Y (6), Ni (4.4), and Ga (3.1). ${ }^{1}$

Although the study area has been contaminated for many years, a rich and preserved mangrove ecosystem resists, which is a habitat for ten of thousands of northhemisphere migratory and resident birds, some of them endangered species globally, such as the Scarlet Ibis (Eudocimus ruber), known as "guará". ${ }^{12}$ Consequently, resident and migratory organisms are exposed to potentially toxic elements, which results in risk of transferring contaminants to the food chain.

Even after decades of environmental monitoring efforts in the Santos-Cubatão Estuarine System, a complete evaluation of the multi-elemental contamination history has not been carried out in estuarine sediment columns. Although previous investigation has shown the extent of contamination in surface sediments at present, the question of whether these levels are higher or lower than those from a recent or older industrial history remains unanswered. In this study, we present multi-elemental geochemical data from a sediment core collected in an estuarine area downstream the Cubatão industrial complex, in order to assess the temporal evolution of contamination in comparison with pre-industrial background levels. In addition, we examine the multi-elemental inter-relationships within sediments as a result of different anthropogenic sources.

\section{Study area: a historical overview of industrial activities}

The Santos-Cubatão Estuarine System comprises a narrow strip between the Atlantic Ocean (Santos Bay) and the Serra do Mar Mountain Range (up to $1000 \mathrm{~m}$ above sea level; Figure 1). The drainage system is developed on sediments coming from the Serra do Mar escarpments, where an important geologic fault (northeast striking) juxtaposes Precambrian metamorphic rocks including phyllites, marbles, schists, quartzites, and calc-silicate rocks of the north fault block, and gneiss-migmatite (Costeiro Complex) of the south block. ${ }^{13}$

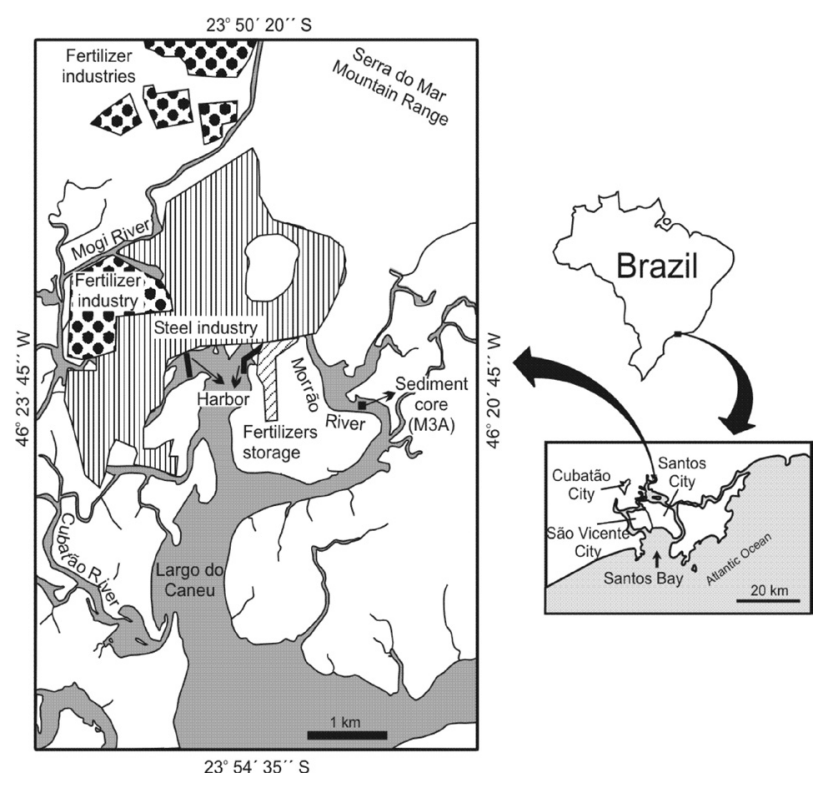

Figure 1. Location of the sediment core in the Morrão River, at the Northeastern part of the Santos-Cubatão Estuarine System, as well as of the fertilizers and steel industries.

The industrial activities in the Municipality of Cubatão until the middle of the $20^{\text {th }}$ century were restricted to leather tanning, coloring, fertilizers, paper, and tannin production, developed, in general, in small factories. In 1955 the petrochemical activities started, when a large refinery began to produce oil derivatives. As a consequence, chemical and fertilizer industries sprouted up nearby. The operation of a steel plant with extensive production dates from 1966, although the first activities (low production) have started in 1963. The production of caustic soda (employing the mercury cell technique) begun in 1964, while the 1970s was the period of fertilizer industries implantation (phosphate and nitrogen-based products) in large scale. ${ }^{14}$ The steel plant and the main fertilizer industry operate their harbors into the estuary (Figure 1), which receive raw materials (both iron and phosphate ores) and ship their productions.

The study site is located within the Morrão River estuary, which is influenced more directly by the steel plant and fertilizers harbor activities (Figure 1). The iron ore used in the steel plant comes from banded iron-formations of the Quadrilátero Ferrífero (Minas Gerais State, Brazil), which is composed of iron oxides (hematite, magnetite, martite), abundant quartz or dolomite, very rare mica, and other accessory minerals. ${ }^{15}$ Harboring activities in the 
vicinity of this river involve phosphate rocks and phosphate fertilizers transport related to the productive process of an industry located about $5 \mathrm{~km} \mathrm{NW}$ from the studied site. The phosphate rocks used by the fertilizer industry come from the Brazilian alkaline-carbonatitic province, especially from the Catalão complex (Goiás State, Brazil). ${ }^{16}$ The mineralogical composition of the phosphate ore is dominated by fluorapatite, goethite and quartz, with minor amounts of Al-phosphates, anatase, magnetite, monazite, and barite. ${ }^{17}$ In the phosphate mines, the ore is treated by flotation-separation processes in order to concentrate P-rich minerals. In the Cubatão industrial complex, the phosphate rock concentrate (mainly composed of apatite), is attacked with $\mathrm{H}_{2} \mathrm{SO}_{4}$ to produce phosphoric acid, hydrogen fluoride and phosphogypsum as a by-product. Phosphogypsum consists mainly of gypsum $\left(\mathrm{CaSO}_{4} \cdot 2 \mathrm{H}_{2} \mathrm{O}\right)$ with variable impurity levels, depending on the type of phosphatic rock.

\section{Experimental}

\section{Sampling and sediment analyses}

In February 2005, a $260 \mathrm{~cm}$ long sediment core (M3A) was collected in the intertidal area of the Morrão River

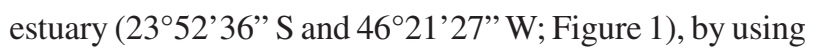
a hand-operated acid-cleaned $\mathrm{PVC}$ pipe $(10 \mathrm{~cm}$ diameter). The core was sectioned every $5 \mathrm{~cm}(0-60 \mathrm{~cm}$ depth $)$ and $10 \mathrm{~cm}$ (below $60 \mathrm{~cm}$ depth). Sediment samples were dried at $50^{\circ} \mathrm{C}$ and stored in plastic bags until laboratory analysis.

Bulk sediments were ground in a mill with agate balls, and $0.25 \mathrm{~g}$ samples of powdered sediment were digested in a $10 \mathrm{~mL}$ acid solution $\left(\mathrm{H}_{2} \mathrm{O}: \mathrm{HF}: \mathrm{HClO}_{4}: \mathrm{HNO}_{3}, 2: 2: 1: 1\right)$. The solutions were heated until fuming on a hot plate and taken to dryness. Then, $4 \mathrm{~mL} 50 \% \mathrm{HCl}$ was added to the residue and heated in a microwave. After cooling the solutions were made to a $10 \mathrm{~mL}$ volume with $5 \% \mathrm{HCl}$. These solutions were analyzed in a Perkin Elmer Elan 6000 ICP-MS (Acme Analytical Laboratories, Canada) for 38 elements, including $\mathrm{Li}, \mathrm{Be}, \mathrm{Na}, \mathrm{Mg}, \mathrm{Al}, \mathrm{P}, \mathrm{S}, \mathrm{K}, \mathrm{Ca}$, $\mathrm{Sc}, \mathrm{Ti}, \mathrm{V}, \mathrm{Cr}, \mathrm{Mn}, \mathrm{Fe}, \mathrm{Co}, \mathrm{Ni}, \mathrm{Cu}, \mathrm{Zn}, \mathrm{Ga}, \mathrm{As}, \mathrm{Rb}, \mathrm{Sr}, \mathrm{Y}, \mathrm{Zr}$, $\mathrm{Nb}, \mathrm{Mo}, \mathrm{Ag}, \mathrm{Cd}, \mathrm{Sn}, \mathrm{Sb}, \mathrm{Cs}, \mathrm{Hf}, \mathrm{Ta}, \mathrm{Pb}, \mathrm{Bi}$, Th, and U. A reference material (LKSD-3-CANMET) and an in-house standard (DST6) were analyzed in the same way as the samples in order to estimate the analytical accuracy (Table S1 as Supplementary Information).

Organic matter content was estimated by loss-onignition at $550{ }^{\circ} \mathrm{C}$ for $4 \mathrm{~h}$, after oven-drying of the sediment samples $(\mathrm{ca} .1 \mathrm{~g})$ to constant weight $(12 \mathrm{~h}$ at $\left.105^{\circ} \mathrm{C}\right) .{ }^{18}$ Grain-size distribution was determined by laser scattering (Cilas 1064 particle analyzer). The samples were dispersed by adding $30 \mathrm{~mL}$ of an aqueous solution of sodium hexametaphosphate $\left(40 \mathrm{~g} \mathrm{~L}^{-1}\right)$ to $3 \mathrm{~g}$ of sediment and shaken for $24 \mathrm{~h}$.

\section{Statistical analysis}

An enrichment factor (EF) was calculated for each element, according to the equation (adapted from Grant): ${ }^{19}$

$\mathrm{EF}=\left(\mathrm{C}_{i} / \mathrm{C}_{R}\right)_{\text {anthropogenic }} /\left(\mathrm{C}_{i} / \mathrm{C}_{R}\right)_{\text {background }}$

where $C_{i}$ and $C_{R}$ refer to the concentrations of $i$ (element of interest) and $\mathrm{R}$ (normalizing element) in the anthropogenic and pre-industrial (background) sediments. The use of a normalizing element is important to minimize the effects of grain-size and mineralogical heterogeneities on the sediment chemical composition. Lithium was used as normalizer in this work due to its uniform distribution in sediments of the Morrão River and in other parts of the Santos-Cubatão Estuarine System. ${ }^{1}$ According to Loring, ${ }^{20}$ lithium provides a good normalization to estimate anthropogenic input of trace-elements to coastal sediments.

Principal component and correlation analyses were applied to identify possible relationships between two or more variables among geochemical data, organic matter contents and grain-size fractions. The geochemical compositions of iron and phosphate ores (literature data) were used for source identification. In addition, historical industrial production data were used to associate the geochemical heterogeneities observed along the core with human activities.

\section{Results and Discussion}

\section{Sediment characteristics}

The studied sediments along the core were mostly muddy, with silt-clay content ranging from $83.4 \%$ to $100 \%$ (2-9\% clay), with the exception of some sandy and sandy-mud layers (Figure 2). Sandy sediments (particles $<1000 \mu \mathrm{m}$ ) were found in $5-10 \mathrm{~cm}$ ( $34.9 \%$ silt-clay), while sandy-mud layers (70-75\% silt-clay) in the 0-5, 100-110 and $140-150 \mathrm{~cm}$ depth intervals. Layers characterized by poorly sorted silt-clay and sand indicate periods with high river runoff. During these periods, the fine particles are transported as suspended matter (including re-suspension), while the coarse fraction is transported at or near the bottom sediment surface, as bedload. ${ }^{21}$ Layers with siltclay content between 83 and $90 \%$ (clay < 4\%) occurred in the $80-100,110-130$ and $150-180 \mathrm{~cm}$ intervals and were 


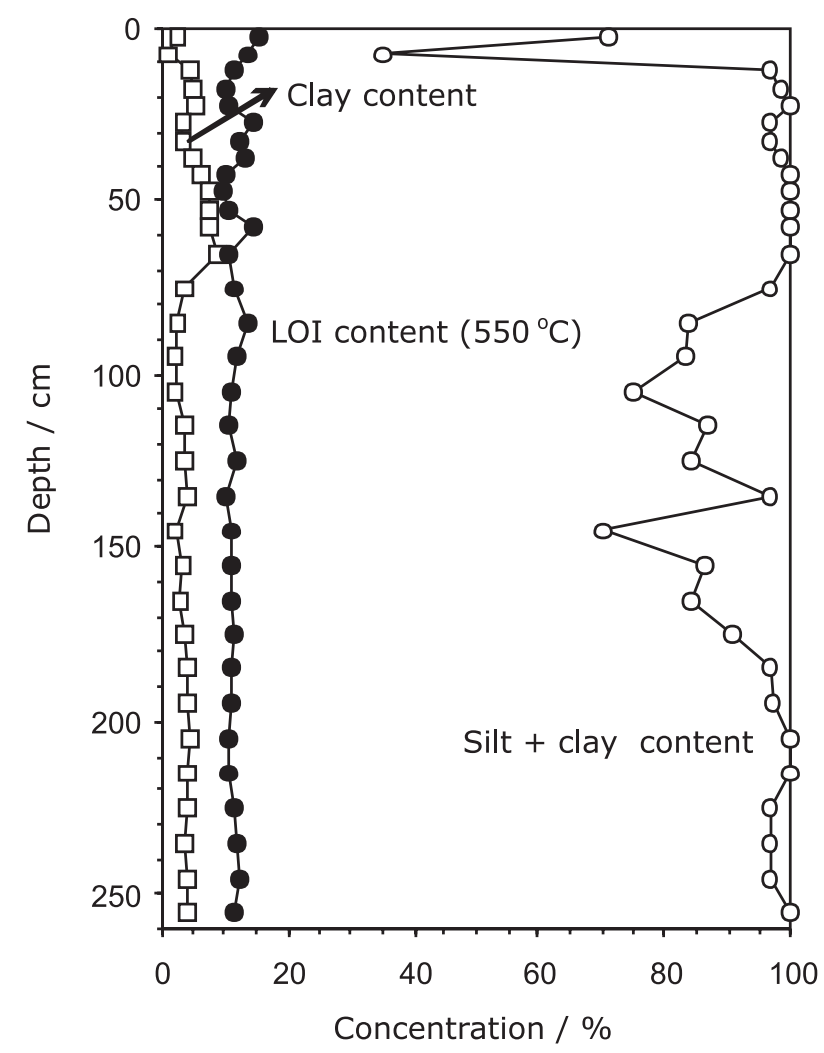

Figure 2. Concentrations of clay, silt-clay and organic matter (LOI) in sediments along the Morrão River core.

interpreted as representing transitions between high and low flow regimes.

Periods of low river runoff were represented by muddier and richly sorted layers in the 10-80, 130-140 and $180-260 \mathrm{~cm}$ intervals, with silt-clay content higher than $96 \%$ (3.5-9\% clay). This suggests that stable sedimentation regimes were dominant along the core. The low flow regime was considered to be more stable at the bottom sediments $(180-260 \mathrm{~cm})$ as shown by low variability in the silt (92.4 to $95.6 \%$ ) and clay (4 to $4.8 \%$ ) contents.

The loss-on-ignition (LOI) data, a proxy for the organic matter content of sediment, ranged between 9.8 and $15.4 \%$ (Figure 2). The concentrations were relatively uniform, showing slightly lower values at the bottom layers $(90-260 \mathrm{~cm}$ ), with an average of $11.3 \%$ (ranging from 10.4 to $12.5 \%$ ), in comparison with those observed in the upper layers $(0-90 \mathrm{~cm})$, with an average of $12.2 \%$ (ranging from 9.8 to $15.4 \%)$.

Considering the relationship among sediment samples in the whole core (not shown), no significant correlations $(\mathrm{p}<0.05)$ were observed between LOI contents and grainsize fractions (sand, silt and clay particles). However, a positive relationship between LOI and sand datasets was obtained $(r=0.34)$, in contrast with negative relationship between LOI and both clay $(\mathrm{r}=-0.34)$ and silt $(\mathrm{r}=-0.32)$ datasets. This suggests that coarse plant particles contribute to organic matter composition, as may be expected for an intertidal area close to the mangrove forest. In fact, the LOI content in the sandy layer $(5-10 \mathrm{~cm}$ depth) was one of the greatest along the core (Figure 2). These particles may represent aggregates and flocks built by clay minerals and organic matter ${ }^{22}$ and/or particulate organic matter in decomposition, including fragments of mangrove leaves, trunks and roots.

\section{Geochemical and contamination profiles}

Geochemical profiles of the Morrão River estuary for 38 elements are shown in Figure 3. Very marked variations in the bulk sediment geochemistry throughout the core are depicted, which are thought to be a result of different mixtures involving the lithogenous source and at least two anthropogenic sources (inputs from the steel plant and fertilizers harbor). These anthropogenic sources are located very close from each other and upstream the study site (Figure 1), while other potential sources of contaminants (petrochemical industries, landfills and domestic wastes discharge) are several kilometers far away. The anomalously high Fe concentrations (Figure 3) were considered as a main marker of the steel plant influence on sediment composition. Sediments with higher Fe contents ( 8.43 to $32.52 \%$; $0-90 \mathrm{~cm}$ ) were considered to be moderately to strongly contaminated, while sediments with lower Fe concentrations (4.59 to 7.34\%; 90-260 cm) presented low or no anthropogenic input. On the other hand, extremely high $\mathrm{P}$ values (a fertilizer industry marker) were found within the first top $110 \mathrm{~cm}$ (4440 to $32160 \mathrm{mg} \mathrm{kg}^{-1}$ ), in contrast to deeper layers ( 650 to $810 \mathrm{mg} \mathrm{kg}^{-1}$ ). Different patterns shown by $\mathrm{Fe}$ and $\mathrm{P}$ concentrations were considered to be due to the particular history of the industrial activities. In fact, fertilizer and steel productions increased markedly ( $>1$ million $\mathrm{t}^{-1}$ ) starting from different years (1975 and 1977, respectively). ${ }^{14}$ So, the sudden increase in Fe (above $90 \mathrm{~cm}$ ) and $\mathrm{P}$ (above $110 \mathrm{~cm}$ ) concentrations in the core (Figure 3) are interpreted to be a result of these industrial episodes.

Based on the above description, two major intervals were considered for analysis: an upper sediment layer $(0-90 \mathrm{~cm})$, which shows high $\mathrm{Fe}$ and $\mathrm{P}$ concentrations due to industrial input, and a lower sediment layer $(110-260 \mathrm{~cm})$, less or not affected by industrial input. Lithium, $\mathrm{Al}, \mathrm{K}$, and $\mathrm{Ti}$ are in general more concentrated in the lower than in the upper sediment layers (Figure 3). These elements have been related to an unpolluted geogenic source in the whole Santos-Cubatão Estuarine System in 

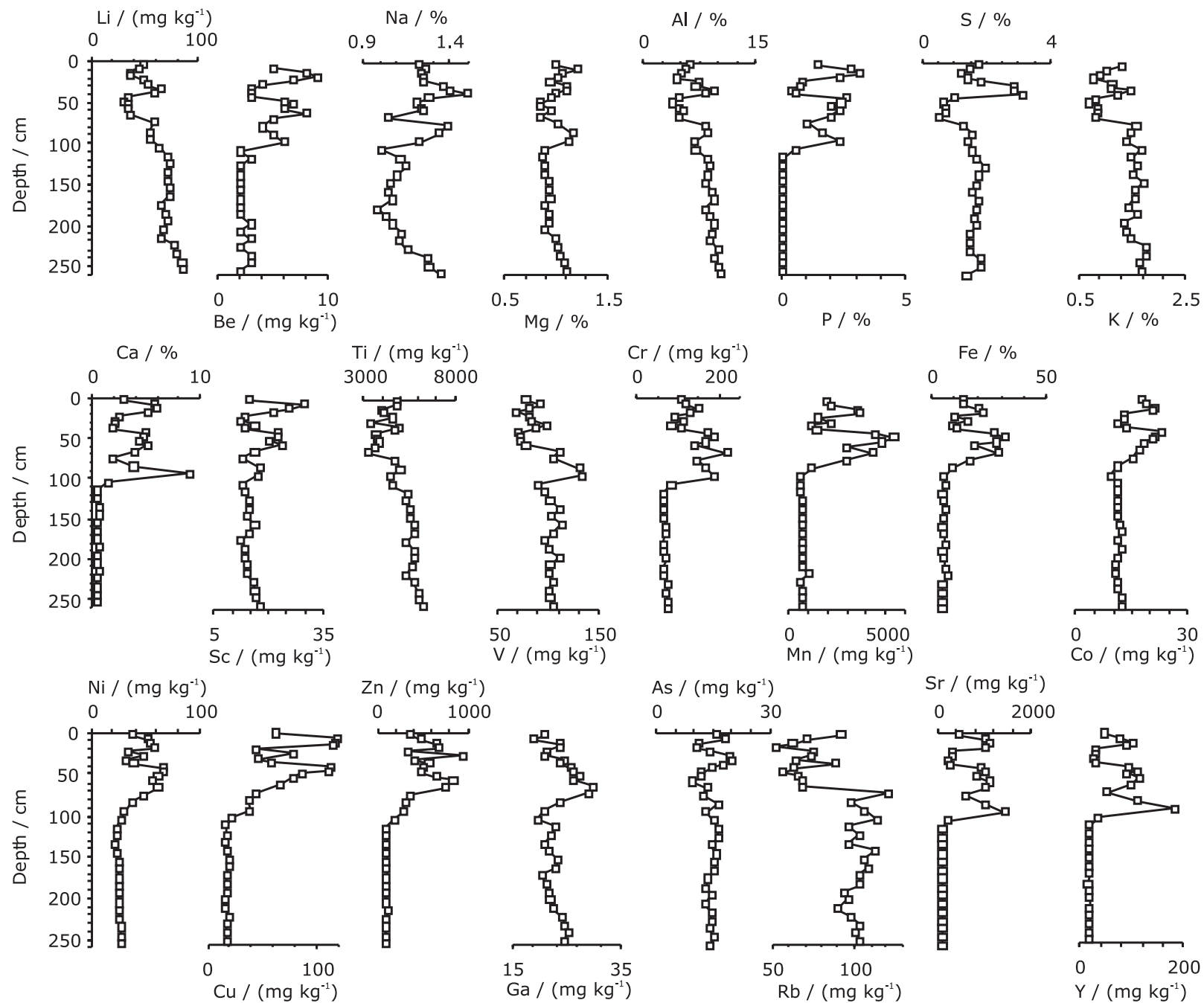

As / $\left(\mathrm{mg} \mathrm{kg}^{-1}\right)$
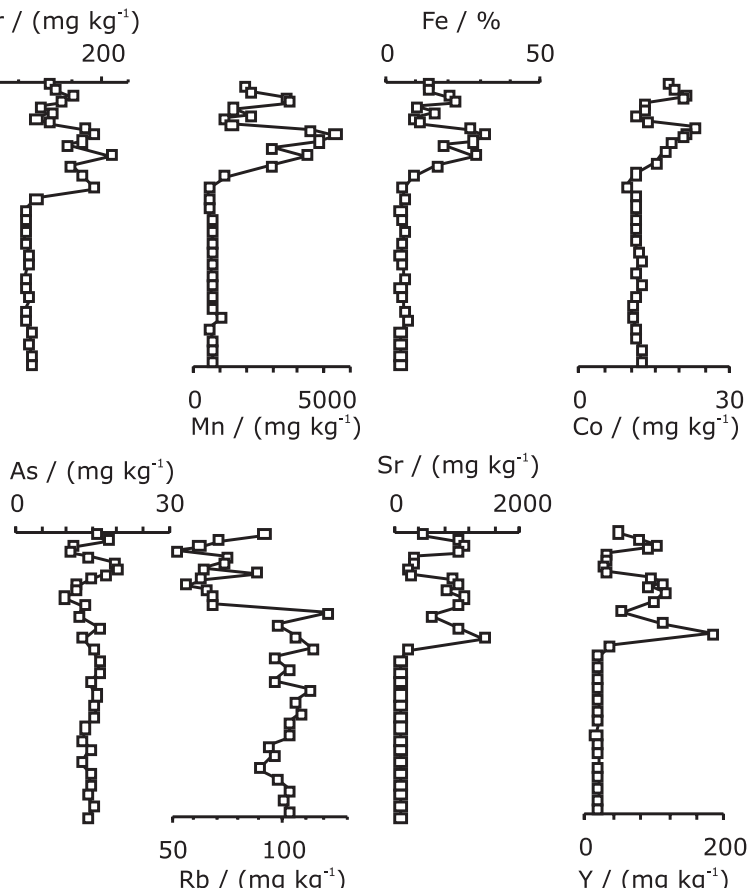

$\mathrm{Sr} /\left(\mathrm{mg} \mathrm{kg}^{-1}\right)$
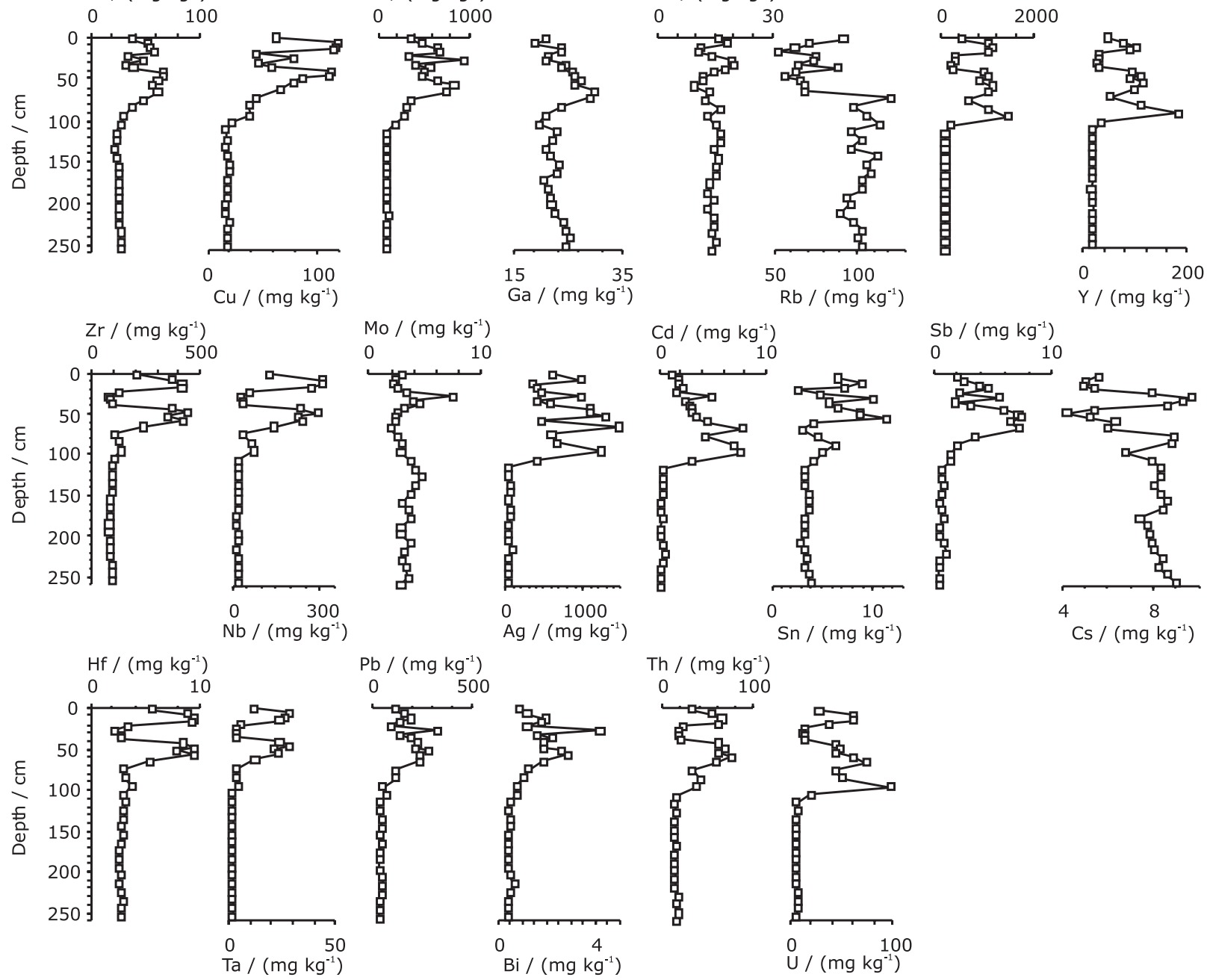

Figure 3. Concentrations of elements in sediments along the Morrão River core. 
Table 1. Concentrations at 220-260 $\mathrm{cm}$ depth in the core (average \pm standard deviation; $\mathrm{n}=4$ ), representative of the geogenic geochemical background for bulk sediments from the Morrão River, Santos-Cubatão Estuarine System. Sodium, Mg, Al, S, K, Ca, Fe are expressed in \% and all other elements are expressed in $\mathrm{mg} \mathrm{kg}^{-1}$

\begin{tabular}{lclclccc}
\hline $\mathrm{Li}$ & $81.6 \pm 3.8$ & $\mathrm{Ti}$ & $5995 \pm 181$ & $\mathrm{As}$ & $14.6 \pm 0.8$ & $\mathrm{Sb}$ & $0.49 \pm 0.05$ \\
$\mathrm{Be}$ & $2.5 \pm 0.6$ & $\mathrm{~V}$ & $103 \pm 2$ & $\mathrm{Rb}$ & $101.5 \pm 2.9$ & $\mathrm{Cs}$ & $8.6 \pm 0.3$ \\
$\mathrm{Na}$ & $1.26 \pm 0.08$ & $\mathrm{Cr}$ & $75 \pm 2$ & $\mathrm{Sr}$ & $99 \pm 5$ & $\mathrm{Hf}$ & $2.81 \pm 0.1$ \\
$\mathrm{Mg}$ & $1.06 \pm 0.04$ & $\mathrm{Mn}$ & $645 \pm 76$ & $\mathrm{Y}$ & $18.1 \pm 0.6$ & $\mathrm{Ta}$ & $1.5 \pm 0.1$ \\
$\mathrm{Al}$ & $10.02 \pm 0.32$ & $\mathrm{Fe}$ & $4.69 \pm 0.12$ & $\mathrm{Zr}$ & $87.9 \pm 1.9$ & $\mathrm{~Pb}$ & $29.52 \pm 3.66$ \\
$\mathrm{P}$ & $725 \pm 59$ & $\mathrm{Co}$ & $11.8 \pm 0.4$ & $\mathrm{Nb}$ & $14.83 \pm 0.34$ & $\mathrm{Bi}$ & $0.40 \pm 0.06$ \\
$\mathrm{~S}$ & $1.62 \pm 0.23$ & $\mathrm{Ni}$ & $27.1 \pm 0.6$ & $\mathrm{Mo}$ & $3.13 \pm 0.33$ & $\mathrm{Th}$ & $15.8 \pm 0.4$ \\
$\mathrm{~K}$ & $1.73 \pm 0.07$ & $\mathrm{Cu}$ & $18.78 \pm 0.23$ & $\mathrm{Ag}$ & $28 \pm 8$ & $\mathrm{U}$ & $5.3 \pm 0.4$ \\
$\mathrm{Ca}$ & $0.41 \pm 0.05$ & $\mathrm{Zn}$ & $92 \pm 5$ & $\mathrm{Cd}$ & $0.2 \pm 0.1$ & & \\
$\mathrm{Sc}$ & $16.7 \pm 0.7$ & $\mathrm{Ga}$ & $24.6 \pm 0.5$ & $\mathrm{Sn}$ & $3.6 \pm 0.3$ & &
\end{tabular}

a recent publication. ${ }^{1}$ As discussed below, the $220-260 \mathrm{~cm}$ depth interval appears to present sediments reflecting the situation before industrialization of the watershed. The average concentrations of $\mathrm{Fe}(4.49 \%)$ and $\mathrm{P}\left(725 \mathrm{mg} \mathrm{kg}^{-1}\right)$ in this depth interval were similar to average values found in shales $\left(4.72 \%\right.$ and $700 \mathrm{mg} \mathrm{kg}^{-1}$, respectively), ${ }^{23}$ indicating no contamination. Thus, we use the concentrations at depth of 220-260 $\mathrm{cm}$ to represent the geochemical background for all elements (Table 1). These background values were generally higher than those obtained for the $<63 \mu \mathrm{m}$ fraction in a sediment profile from the Casqueiro River, southwestern Santos-Cubatão Estuarine System, ${ }^{1}$ probably because this previous study employed a partial (aqua regia) extraction method.

Average enrichment factors for top $(0-90 \mathrm{~cm})$ and bottom $(110-220 \mathrm{~cm})$ sediment layers are presented in Figure 4 . In both cases, $\mathrm{Li}, \mathrm{Al}, \mathrm{K}, \mathrm{Ti}$, and $\mathrm{Rb}$ showed average $\mathrm{EF}$ values $c a$. 1 . Some elements showed low average EF values (1.0 to 1.3 ) at the bottom layer and slightly higher (1.4 to 1.8) at the top layer, such as $\mathrm{Na}, \mathrm{Mg}, \mathrm{S}, \mathrm{V}, \mathrm{As}, \mathrm{Cs}$, and Mo. The peak enrichment for these elements at the top of the core ranged between 2.2 and 2.8, except Cs
(1.8 factors) and Mo (3.7). This slight enrichment of certain elements at the top layer may possibly be explained by a low anthropogenic input.

A large number of elements showed significant enrichment factors within the upper layers, in contrast to low values at the bottom layers (Figure 4). Average EF values ranged from 2 to 6.2 for $\mathrm{Zr}$, Th, $\mathrm{Hf}, \mathrm{Be}, \mathrm{Ni}, \mathrm{Cr}$, $\mathrm{Sn}, \mathrm{Co}, \mathrm{Sc}$, and $\mathrm{Ga}$ (in decreasing order) within the upper layers. However, several elements presented much higher average EF values, such as $\mathrm{Ag}$ (54.5 factors), P (51.1), Cd (37.5), $\mathrm{Nb}$ (23.3), Ta (21.7), Ca (19.0), $\mathrm{Sb}$ (18.6), $\mathrm{Sr}$ (15.6), $\mathrm{U}$ (15.2), Pb (12.3), Zn (11.8), Mn (9.4), Bi (9.4), Cu (8.6), $\mathrm{Y}(8.5)$, and $\mathrm{Fe}(8.1)$.

\section{Geochemical signature and source markers}

Principal component analysis (PCA) was used in order to summarize the major geochemical variation patterns and to support the identification of contaminant sources for the main contaminated layer $(0-90 \mathrm{~cm})$. Two meaningful components were obtained, which explained $70.33 \%$ of the total variance, with the first component accounting for

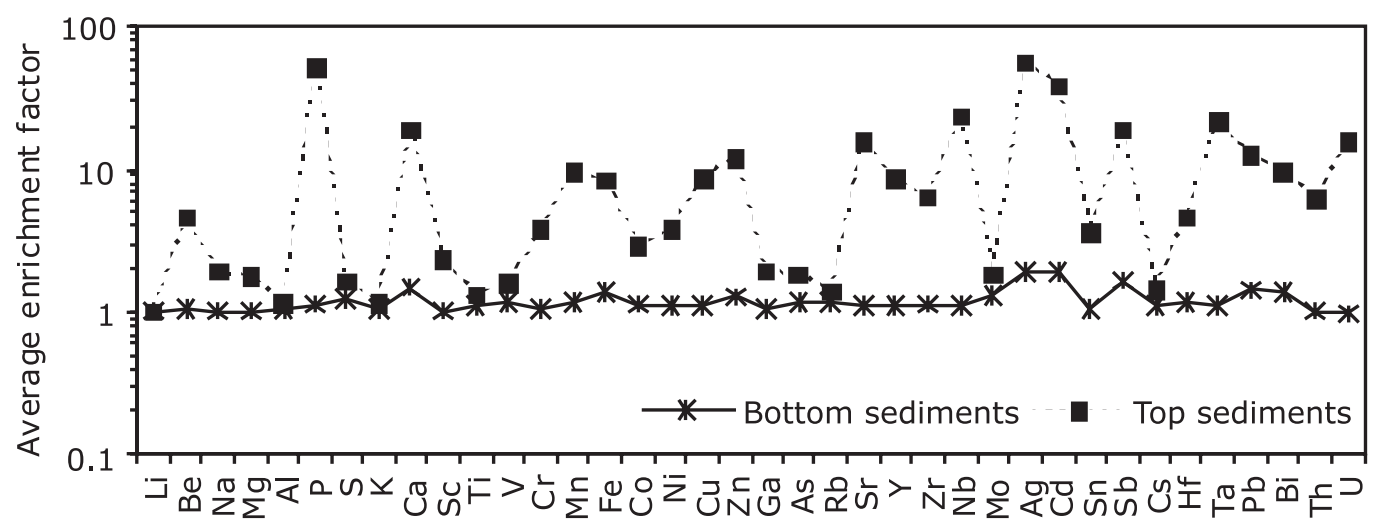

Figure 4. Average enrichment factors for the top $(0-90 \mathrm{~cm}$ depth; $\mathrm{n}=15)$ and bottom $(110-220 \mathrm{~cm}$ depth; $\mathrm{n}=11)$ of the Morrão River core. 

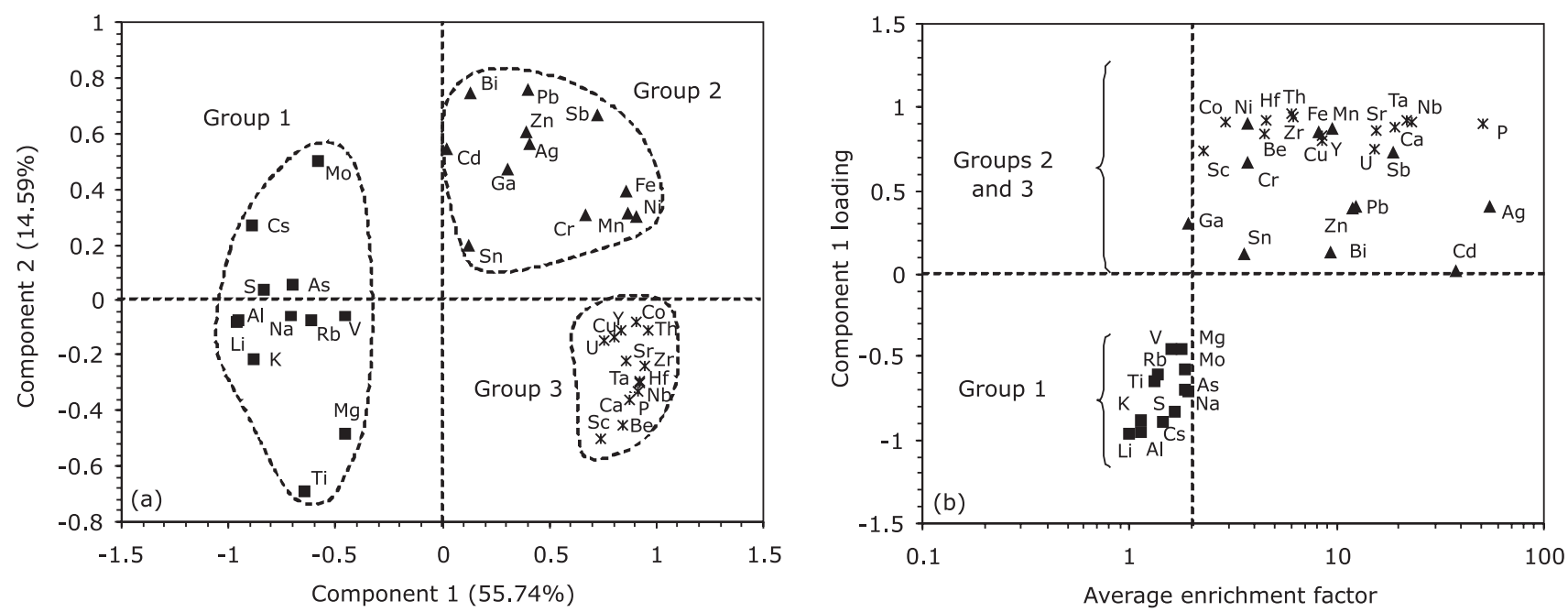

Figure 5. Scatter diagrams for the $0-90 \mathrm{~cm}$ depth of the Morrão River core ( $\mathrm{n}=15)$ : (a) first two principal components (\% of variance indicated) and (b) component 1 plotted against average enrichment factor.

$55.74 \%$ and the second for $14.59 \%$ of this variance. As can be seen in Figure $5 \mathrm{a}$, a set of elements ( $\mathrm{Li}, \mathrm{Na}, \mathrm{Mg}, \mathrm{Al}, \mathrm{S}, \mathrm{K}$, $\mathrm{Ti}, \mathrm{V}, \mathrm{As}, \mathrm{Rb}, \mathrm{Mo}$, and Cs) showed negative loadings of the component 1 . All of these elements (group 1) showed low average EF values (1.0 to 1.8, Figure 5b) and are thought to be geogenic or present minor anthropogenic influence, as mentioned above. Figure 5a shows also two other sets of elements formed in association with $\mathrm{Fe}$ (group 2) or $\mathrm{P}$ (group 3). These sets of elements contribute positively to the component 1 , while component 2 distinguishes between positive loadings ( $\mathrm{Cr}, \mathrm{Mn}, \mathrm{Fe}, \mathrm{Ni}, \mathrm{Zn}, \mathrm{Ga}, \mathrm{Ag}, \mathrm{Cd}$, $\mathrm{Sn}, \mathrm{Sb}, \mathrm{Pb}$, and $\mathrm{Bi}$ ) and negative loadings ( $\mathrm{Be}, \mathrm{P}, \mathrm{Ca}, \mathrm{Sc}$, $\mathrm{Co}, \mathrm{Cu}, \mathrm{Sr}, \mathrm{Y}, \mathrm{Zr}, \mathrm{Nb}, \mathrm{Hf}, \mathrm{Ta}, \mathrm{Th}$, and U). These two sets of elements are interpreted to be more related to the steel (group 2) and fertilizers (group 3) production processes, with different contribution levels, as indicated by average $\mathrm{EF}$ values (Figure 5b).

Considering the entire core, strong positive correlations $(\mathrm{r}=0.86$ to $0.96 ; \mathrm{p}<0.05)$ were found between $\mathrm{Li}, \mathrm{Al}, \mathrm{K}$, and $\mathrm{Ti}$, which are important clay mineral constituents (Table S2, correlation matrix in the Supplementary Information). The correlations of these lithogenous elements with Cs, $\mathrm{Rb}$ and $\mathrm{V}$ were also significant ( $\mathrm{r}=0.53$ to 0.88 ; $\mathrm{p}<0.05$ ), suggesting a possible common origin from silicate minerals. In addition, high correlation coefficients $(r=0.63$ to 0.76 ; $\mathrm{p}<0.05$ ) were obtained for chalcophile elements ( $\mathrm{S}$, As and Mo), suggesting that these elements could be incorporated in sulfide phases. On the other hand, reasonable correlations between $\mathrm{Na}, \mathrm{Mg}$ and LOI $(\mathrm{r}=0.49$ to $0.59 ; \mathrm{p}<0.05)$ suggest that organic matter may be an important binding phase for these metals. The lack of positive correlations between grain-size and group 1 elements (Table S2, in Supplementary Information) suggests that the sediment texture does not play a significant role on the concentrations of these elements.

A previous study that evaluated sediments from some rivers of the Santos-Cubatão Estuarine System supports the geogenic source of $\mathrm{Li}, \mathrm{Mg}, \mathrm{Al}, \mathrm{K}, \mathrm{Ti}, \mathrm{V}$, and As, while Na, $\mathrm{S}, \mathrm{Cs}, \mathrm{Rb}$, and Mo were not investigated. ${ }^{1}$

The contamination potential of the steel production process has been largely studied, and in general the traceelement inputs to the environment may be significant, ${ }^{24-26}$ as suggested by set of elements displayed in group 2 (Figure 5a). We examined previous works on the concentrations of some of these elements in the iron ores used in the steel plant of the present study, originated from some ore deposits of the Quadrilátero Ferrífero (Minas Gerais State, Brazil), including the Águas Claras deposit. According to Klein and Ladeira, ${ }^{15}$ the range of nickel concentrations is 6-39 $\mathrm{mg} \mathrm{kg}^{-1}$ in both dolomitic (alternating dolomite-rich and hematite-rich bands) and siliceous (alternating quartzrich and hematite-rich bands) ores from Águas Claras. Spier et al. ${ }^{27}$ showed concentration intervals of $<0.01-0.43 \%$ $\mathrm{MnO}$ ( or $<77-3330 \mathrm{mg} \mathrm{kg}^{-1} \mathrm{Mn}$ ), 0.2-3.4 $\mathrm{mg} \mathrm{kg}^{-1} \mathrm{Sb}$, $<3-10.1 \mathrm{mg} \mathrm{kg}^{-1} \mathrm{~Pb}$, and $0.1-6.0 \mathrm{mg} \mathrm{kg}^{-1} \mathrm{Bi}$ in the same ores. Considering that the mineral product (concentrate) used in the steel plant contains higher contents of hematite,,$^{15}$ and certainly other heavy minerals, the concentrations of $\mathrm{Mn}, \mathrm{Ni}, \mathrm{Sb}, \mathrm{Pb}$, and $\mathrm{Bi}$ in this product can be still higher than the values shown above. In addition, manganese is used primarily in steel production, resulting in further $\mathrm{Mn}$ inputs to the Morrão River sediments. In respect to the group 3 elements (Figure 5a), phosphate rocks used as raw materials to produce fertilizers (or by-product such as phosphogypsum), are supposed to be potential sources for enrichment of these elements in these sediments. 
The harbor in the Morrão River vicinity receives raw materials and phosphate fertilizers from one factory that uses phosphate concentrate from the Brazilian alkalinecarbonatitic province, in which Catalão and Tapira are the main ore deposits. Bragança et al. ${ }^{28}$ showed high concentrations of $\mathrm{Ca}(16.2 \pm 0.2 \%)$, Sc $\left(55 \pm 3 \mathrm{mg} \mathrm{kg}^{-1}\right)$ and $\mathrm{Th}\left(240 \pm 40 \mathrm{mg} \mathrm{kg}^{-1}\right)$ in the phosphate ore from Catalão deposit. In addition, Conceição and Bonotto ${ }^{29}$ showed industrial products from Tapira ore with average concentrations as high as $7.6 \% \mathrm{P}, 36.5 \% \mathrm{Ca}$ and $1 \% \mathrm{SrO}$ (or $8456 \mathrm{mg} \mathrm{kg}^{-1} \mathrm{Sr}$ ).

It is important to keep in mind that the major contamination potential of each anthropogenic source in the study area becomes evident for the set of elements with higher affinity to the ore provided that this characteristic is maintained after deposition. This geochemical control was attested by comparing correlation coefficients among the element concentrations shown in Table S3 (correlation matrix as Supplementary Information). The group 3 (elements associated with $\mathrm{P}$ ) displayed in the PCA (Figure 5a) are more strongly inter-correlated $(\mathrm{p}<0.05)$ than the group 2 (elements associated with Fe; Table S3, Supplementary Information). Significant correlations took place between all the metals from group 3 and $\mathrm{P}(\mathrm{r}=0.81$ to 0.98). On the other hand, significant correlations between $\mathrm{Fe}$ and metals from group 2 were obtained only for $\mathrm{Cr}, \mathrm{Mn}$, $\mathrm{Ni}$, and $\mathrm{Sb}$ ( $\mathrm{r}=0.77$ to 0.99 ), minor correlations for $\mathrm{Ga}, \mathrm{Ag}$ and $\mathrm{Pb}(\mathrm{r}=0.53$ to 0.64$)$, while no significant relationships were shown between $\mathrm{Fe}$ and $\mathrm{Zn}, \mathrm{Cd}, \mathrm{Sn}$, and $\mathrm{Bi}$ (the last four elements have not shown any correlation with P). Table S3 reveals that the correlations between elements from groups 2 and 3 were also significant in several cases. It may result from contributions from more than one source of contamination or strong post-depositional sediment mixing and diagenetic redistribution of elements. A geochemical signature evaluation could help to explain the historic input of some elements. We examined the inter-relationships shown by $\mathrm{P}$ and $\mathrm{Fe}$ and some other anomalous elements $(\mathrm{Cr}, \mathrm{Zn}, \mathrm{Zr}, \mathrm{Cd}$, and $\mathrm{Th})$, whose concentrations in the ores of interest have been reported in the literature. Figure 6 shows the average concentrations of these elements in phosphate concentrates from Tapira ${ }^{29}$ and Catalão ore deposits, ${ }^{16}$ and in iron concentrates from Águas Claras ore deposit. ${ }^{27} \mathrm{As}$ can be seen in this figure, the concentrations of $\mathrm{Zn}$ and $\mathrm{Cd}$ were of the same order of magnitude in both phosphate and iron concentrates. So, the lack of correlation of $\mathrm{P}$ and Fe with these metals (Table S3, Supplementary Information) could be a consequence of mixing of multiple anthropogenic sources. On the other hand, the contamination potential of phosphate ore for $\mathrm{Zr}$ and $\mathrm{Th}$ is much higher (167 and 515 times, respectively) than that of iron ore. As a result, the correlations of these elements with $\mathrm{P}(\mathrm{r}=0.90$, for both elements) were much higher than with $\mathrm{Fe}(\mathrm{r}=0.69$ and 0.74 , respectively). In addition, iron ore contamination potential for $\mathrm{Cr}$ is 13 times larger than that of phosphate ore. This may explain why a larger correlation coefficient between $\mathrm{Cr}$ and $\mathrm{Fe}$ contents was found $(\mathrm{r}=0.77)$, in comparison with that between $\mathrm{Cr}$ and $\mathrm{P}$ contents $(\mathrm{r}=0.56)$.

The EF values profiles with particular peaks for $\mathrm{P}$ and Fe could also help to understand the complexity of the geochemical association degree (Figure 7). Note that the $P$ profile shows positive $(95 \mathrm{~cm})$ and negative $(75 \mathrm{~cm})$ peaks (both absent in Fe profile), while the Fe pattern exhibits positive peak in $27.5 \mathrm{~cm}$ (absent in the P pattern). Elements such as $\mathrm{Cr}, \mathrm{Zn}$ and $\mathrm{Cd}$ showed similarity with both $\mathrm{Fe}$ and $\mathrm{P}$ signatures, while $\mathrm{Zr}$ and $\mathrm{Th}$ were only consistent with the $\mathrm{P}$ signature. Therefore, the inter-elemental relationships along the studied core are thought to be more expressive according to the contamination potential of each particular anthropogenic source. However, since elements may show different behavior during diagenesis, ${ }^{30}$ the vertical distribution within the sediments may also be partially explained by different responses to authigenic processes, which may change the original correlations.

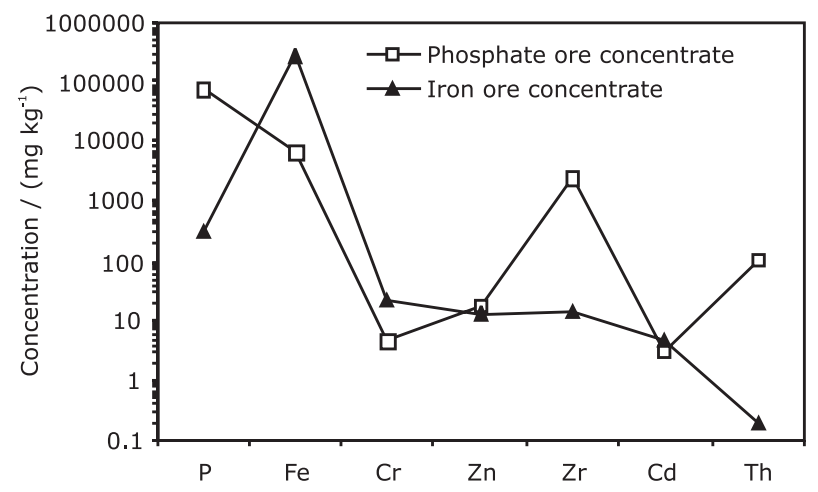

Figure 6. Average concentrations of selected elements in phosphate and iron ore concentrates. The phosphate ore data such as $\mathrm{Zr}$ and $\mathrm{Th}$ are from the Catalão deposit $(\mathrm{n}=6)$ and $\mathrm{P}, \mathrm{Fe}, \mathrm{Cr}, \mathrm{Zn}$ and $\mathrm{Cd}$ are from the Tapira deposit $(n=2)$. All element concentrations in the iron ore are referred to the Águas Claras deposit (iron-rich band; $n=6$ ).

\section{Sedimentation history using iron as a chronologic marker}

The ${ }^{210} \mathrm{~Pb}$ dating techniques for determining sediment accumulation rates are not reliable for the Morrão River estuary due to high levels of radionuclide contamination from fertilizer industry wastes..$^{10}$ As the anthropogenic Fe source for the studied site is related to a steel plant, alternatively, the annual steel industrial production (1966 to 2004) was compared to the Fe distribution along the core (Figure 8) 


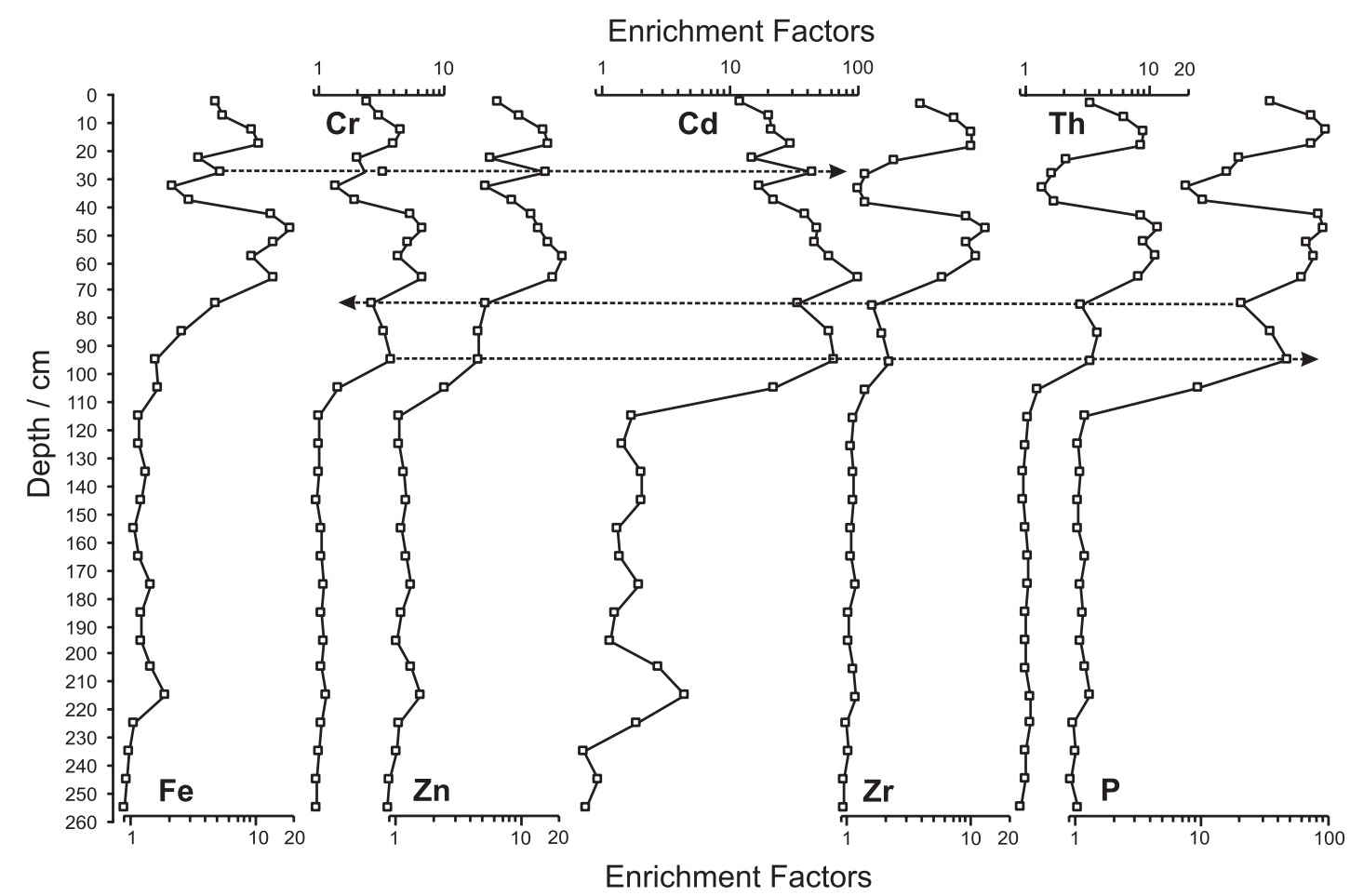

Figure 7. Enrichment factors for $\mathrm{Fe}, \mathrm{Cr}, \mathrm{Zn}, \mathrm{Cd}, \mathrm{Zr}$, Th and $\mathrm{P}$ along the Morrão River core. The top arrow indicates one peak in the Fe pattern, which is absent in the $\mathrm{P}$ pattern. The two lower arrows point to peaks in the P profile, absent in the Fe profile. The $\mathrm{Zr}$ and Th patterns are similar only to the $\mathrm{P}$ pattern, and the $\mathrm{Cr}, \mathrm{Zn}$ and $\mathrm{Cd}$ profiles show some similarity with both $\mathrm{P}$ and Fe patterns.

in order to determine sedimentation rates and to date the sediments (e.g. Louchouarn and Lucotte).$^{31}$ It is important to note that the fertilizer harbor in the vicinity of the studied site is considered comparatively a less important source of Fe for sediments from the Morrão River, as suggested by relatively low concentration of this metal in the phosphate ore (Figure 6). The Fe peak (7.34\%) in $215 \mathrm{~cm}$ (Figure 8) seems to roughly represent the period of the steel plant construction, i.e. 1959 to $1963 .{ }^{14}$ This construction involved large quantities of steel and concrete, which may be also reflected, for instance, in the coincident Mn (steel constituent) and $\mathrm{Ca}$ (concrete constituent) peaks in this depth, besides other elements (Figure 3). The productive process in the steel plant began in 1963 and until 1965 the production is thought to have been low (data are not available). The first register of the steel production dates from $1966\left(431,000 \mathrm{t} \mathrm{y}^{-1}\right)$, and the production increased progressively until 1976 $\left(789,000 \mathrm{t} \mathrm{y}^{-1}\right) \cdot{ }^{14}$ Note in Figure 8 that Fe concentrations in the 95-225 cm depth interval differ only slightly (except the peak at $215 \mathrm{~cm}$ ) from those below $225 \mathrm{~cm}$ depth, in which sediments would have been deposited before major anthropogenic activity in the watershed. So, this less expressive steel production period does not seem to have modified significantly the Fe levels throughout the core, and a high sedimentation rate $\left(7.6 \mathrm{~cm} \mathrm{y}^{-1}\right)$ was estimated for $95-225 \mathrm{~cm}$ depth (around 1959 to 1976).
The sudden increase in Fe concentrations observed just above $95 \mathrm{~cm}$ depth reflects an accelerated steel production, which reached 1.539 Mt in 1977 (Figure 8). An increasing steel production (up to $3.0 \mathrm{Mt}$ ) between 1977 and 1983 explains the highest Fe concentration in $47.5 \mathrm{~cm}$, reaching $32.52 \%$ (corresponding to the year 1983). In opposition, above $47.5 \mathrm{~cm}$ a trend of decreasing Fe concentrations was found, which was consistent with the implementation of pollution control measures in $1984 .{ }^{3}$ In spite of these measures, the $\mathrm{Fe}$ distribution pattern above $47.5 \mathrm{~cm}$ followed the industrial production trend up to $10 \mathrm{~cm}$ depth, above which there were nearly constant Fe concentrations, while steel production increased. Sedimentation rates were estimated as $6.6 \mathrm{~cm} \mathrm{y}^{-1}$ for the $42.5-95 \mathrm{~cm}$ depth interval (corresponding to $c a$. 1976-1984 = maximum contamination level) and $3.3 \mathrm{~cm} \mathrm{y}^{-1}$ for the $32.5-42.5 \mathrm{~cm}$ depth interval (corresponding to $c a$. 1984-1987). The more recent sedimentation rate (upper $32.5 \mathrm{~cm}$ depth), relative to near 1987 to 2004, was estimated in $1.9 \mathrm{~cm} \mathrm{y}^{-1}$. This rate is comparable to that found in some recent sedimentary environments in Brazilian coast, such as Guanabara Bay $\left(1.6 \pm 0.6 \mathrm{~cm} \mathrm{y}^{-1}\right) .{ }^{32}$ On the other hand, rates as high as those found below $42.5 \mathrm{~cm}$ depth in the present study are less frequent in the literature, as reported for the northeastern region of Sepetiba Bay/Brazil (up to $\left.6 \mathrm{~cm} \mathrm{y}^{-1}\right) .33$ 


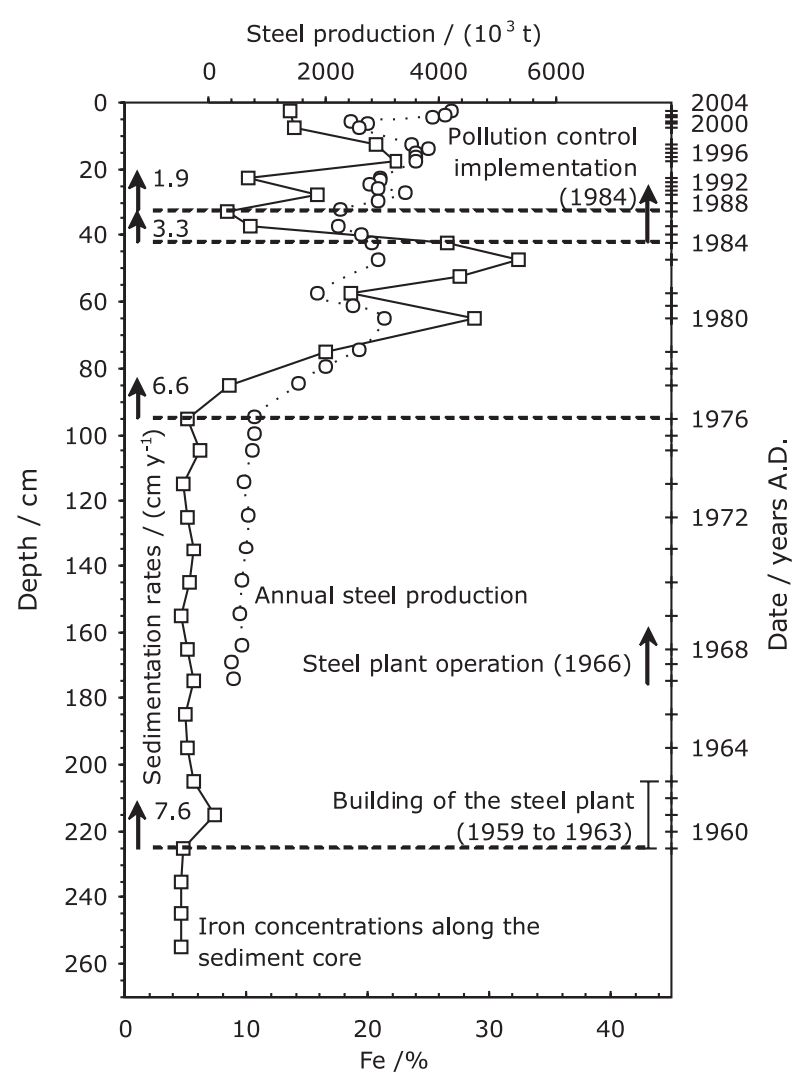

Figure 8. Comparison of Fe concentrations in bulk sediments along the Morrão River core and steel production ${ }^{14}$ pattern in the study area. The overlap of both Fe concentration and steel production peaks make the estimation of sedimentation rates possible, which is consistent with the records of the main industrial events and the implementation of a pollution control policy. Sedimentation rates calculation: $(32.5 \mathrm{~cm}) /(2004-1987)=$ $1.9 \mathrm{~cm} \mathrm{y}^{-1} ;(42.5-32.5 \mathrm{~cm}) /(1987-1984)=3.3 \mathrm{~cm} \mathrm{y}^{-1} ;(95-42.5 \mathrm{~cm}) /$ $(1984-1976)=6.6 \mathrm{~cm} \mathrm{y}^{-1} ;(225-95 \mathrm{~cm}) /(1976-1959)=7.6 \mathrm{~cm} \mathrm{y}^{-1}$.

High sediment deposition rates could reflect both anthropogenic activities and storm events or other high flow periods. Heavy rains are frequent in the study region. These have resulted in many landslides (debris flow) in the Serra do Mar Mountain Range, as recorded in 1967, 1971, 1976, and $1999 .{ }^{34,35}$ More poorly sorted sediments in some depths along the core (e.g., 0-10, 85-125 and 145-175 cm depth intervals) may indicate those periods of higher river runoff. According to Gramani and Kanji, ${ }^{35}$ the sediment features related to debris flow events in this area depend on geomorphology and proximity of the Serra do Mar escarpments. As the studied site within the Morrão River estuary is very close to the Serra do Mar escarpments, these episodic gravitational mass movements appear to have affected the sedimentation regimes.

\section{Conclusions}

Within the Santos-Cubatão Estuarine System, sediments from the Morrão River estuary showed high concentrations of multiple chemical contaminants. The composition of the sediment core samples results from variable contributions in time from lithogenous inputs and the influence of two anthropogenic sources (a steel plant and a fertilizer industry harbor). Based on integrated analyses of enrichment factors (EF), principal component analyses, correlation matrixes, and geochemical signatures, concentrations of elements such as $\mathrm{Li}, \mathrm{Na}, \mathrm{Mg}$, $\mathrm{Al}, \mathrm{S}, \mathrm{K}, \mathrm{Ti}, \mathrm{V}, \mathrm{As}, \mathrm{Rb}, \mathrm{Mo}$, and Cs were considered to be geogenic or least influenced by anthropogenic activities. In contrast, the relationships between anthropogenic source markers and two sets of contaminant elements were recorded in the sediment column. A set of elements (Cr, Mn, Ni, Zn, Ga, Ag, Cd, Sn, Sb, Pb, and Bi) showed association with steel plant-derived $\mathrm{Fe}$ concentrations. In addition, elements such as $\mathrm{Be}, \mathrm{Ca}, \mathrm{Sc}, \mathrm{Co}, \mathrm{Cu}, \mathrm{Sr}, \mathrm{Y}$, $\mathrm{Zr}, \mathrm{Nb}, \mathrm{Hf}, \mathrm{Ta}, \mathrm{Th}$, and $\mathrm{U}$ were strongly associated with fertilizer industry-derived P concentrations. However, the recorded geochemical signatures suggested that more than one source contributed to the distribution of the same contaminant.

For the study site, which presents a complex mingling of physical and geochemical anthropogenic disturbances that make the application of conventional dating methods difficult, Fe appears to be a reliable marker of the contamination history. Sedimentation rates based on the iron geochemical signature and the history of steel production ranged from 7.6-3.3 $\mathrm{cm} \mathrm{y}^{-1}$ (1959 to 1987) to $1.9 \mathrm{~cm} \mathrm{y}^{-1}$ (1987 to 2004). These high deposition rates may have been influenced not only by anthropogenic activities but also by gravitational mass movement (debris flows) along the Serra do Mar escarpments.

\section{Supplementary Information}

Tables S1 (reference material analysis results), S2 and S3 (correlation matrixes for geogenic and anthropogenic elements, respectively) are available free of charge via internet at http://jbcs.sbq.org.br.

\section{Acknowledgments}

We thank the financial support from FAPESP (Project No. 04/00059-6) and the critical comments from two anonymous referees. The authors are also grateful to Prof. Dr. G. M. Garda for assistance with the text.

\section{References}

1. Luiz-Silva, W.; Matos, R. H. R.; Kristosch, G. C.; Machado, W.; Quim. Nova 2006, 29, 256. 
2. CETESB (Companhia de Tecnologia de Saneamento Ambiental); Avaliação Preliminar da Contaminação por Metais Pesados na Água, Sedimento e Organismos Aquáticos do Rio Cubatão (SP), Relatório Técnico, 1989.

3. Lemos, M. C. M.; J. Environ. Dev. 1998, 7, 60.

4. CETESB (Companhia de Tecnologia de Saneamento Ambiental); Metais Pesados na Baía de Santos e Estuários de Santos e São Vicente, Relatório Técnico, 1981.

5. Boldrini, C. V.; Pereira, D. N.; Ambiente 1987, 1, 118.

6. Gutberlet, J.; Cubatão: Desenvolvimento, Exclusão Social, Degradação Ambiental, Edusp: São Paulo, 1996.

7. Braga, E. S.; Bonetti, C. V. D. H.; Burone, L.; Bonetti Filho, J.; Mar. Pollut. Bull. 2000, 40, 165.

8. Silva, P. S. C.; PhD Thesis, Universidade de São Paulo, Brazil, 2004.

9. Hortellani, M. A.; Sarkis, J. E. S.; Bonetti, J.; Bonetti, C.; J. Braz. Chem. Soc. 2005, 16, 1140.

10. Machado, W.; Luiz-Silva, W.; Sanders, C. J.; Patchineelam, S. R.; J. Environ. Radioact. 2008, 99, 1329.

11. Martins, C. C.; Mahiques, M. M.; Bícego, M. C.; Fukumoto, M. M.; Montone, R. C.; Mar. Pollut. Bull. 2007, 54, 226.

12. Matos, R. H. R.; PhD Thesis, Universidade Estadual Paulista, Brazil, 2002.

13. Almeida, F. F. M.; Carneiro, C. D. R.; Rev. Bras. Geociências 1998, 28, 135.

14. Couto, J. M.; PhD Thesis, Universidade Estadual de Campinas, Brazil, 2003.

15. Klein, C.; Ladeira, E. A.; Econ. Geol. 2000, 95, 405.

16. Oliveira, S. M. B.; Silva, P. S. C.; Mazzilli, B. P.; Favaro, D. I. T.; Saueia, C. H.; Appl. Geochem. 2007, 22, 837.

17. Oliveira, S. M. B.; Imbernon, R. A.; J. S. Am. Earth Sci. 1998, 11,379 .

18. Heiri, O.; Lotter, A. F.; Lemcke, G.; J. Paleonlimnol. 2001, 25, 101.

19. Grant, J. A.; Econ. Geol. 1986, 81, 1976.

20. Loring, D. H.; J. Mar. Sci. 1991, 48, 101.
21. Helland, A.; Water, Air, Soil Pollut. 2001, 126, 339.

22. Glasby, G. P.; Szefer, P.; Geldon, J.; Warzocha, J.; Sci. Total Environ. 2004, 330, 249.

23. Turekian, K. K.; Wedepohl, K. H.; Geol. Soc. Am. Bull. 1961, $72,175$.

24. Telmer, K.; Bonham-Carter, G. F.; Kliza, D. A.; Hall, G. E. M.; Geochim. Cosmochim. Acta 2003, 68, 2961.

25. Mason, R. P.; Kim, E. -H.; Cornwell, J.; Appl. Geochem. 2004, 19, 1801.

26. Geagea, M. L.; Stille, P.; Millet, M.; Perrone, T.; Sci. Total Environ. 2007, 373, 404.

27. Spier, C. A.; Oliveira, S. M. B.; Sial, A. N.; Rios, F.; J. Precambrian Res. 2007, 152, 170.

28. Bragança, M. J. C. S.; Tauhata, L.; Clain, A. F.; Moreira, I.; Appl. Radiat. Isot. 2004, 61, 351.

29. Conceição, F. T.; Bonotto, D. M.; Environ. Pollut. 2006, 139, 232.

30. Salomons W.; Förstner, U.; Metals in the Hydrocycle, SpringerVerlag: Berlim, 1984.

31. Louchouarn, P.; Lucotte, M.; Sci. Total Environ. 1998, 213, 139.

32. Godoy, J. M.; Moreira, I.; Bragança, M. J.; Wanderley, C.; Mendes, L. B.; J. Radioanal. Nucl. Chem. 1998, 227, 157.

33. Barcellos, C.; Rezende, C. E.; Pfeiffer, W. C.; Mar. Pollut. Bull. 1991, 22, 558.

34. Kanji, M. A.; Massad, F.; Cruz, P. T.; Abstract of the International Workshop on Occurrence and Mechanism of Flows in Natural Slopes and Earthfills, Sorrento, Italy, 2003.

35. Gramani, M. F.; Kanji, M. A.; Abstract of the $3^{a}$ Conferência Brasileira sobre Estabilidade de Encostas, Rio de Janeiro, Brazil, 2001.

Received: January 8, 2008

Web Release Date: September 19, 2008

FAPESP helped in meeting the publication costs of this article. 


\title{
Multi-Elemental Contamination and Historic Record in Sediments from the Santos-Cubatão Estuarine System, Brazil
}

\author{
Wanilson Luiz-Silva, ${ }^{*}, a$ Wilson Machado ${ }^{b}$ and Rosa H. R. Matos ${ }^{c}$ \\ ${ }^{a}$ Instituto de Geociências, Universidade Estadual de Campinas, CP 6152, 13083-970 Campinas-SP, Brazil \\ ${ }^{b}$ Departamento de Geoquímica, Universidade Federal Fluminense, 24020-150 Niterói-RJ, Brazil \\ ${ }^{c}$ R. Aglair Buratto Villas Boas, 508, 13087-725 Campinas-SP, Brazil
}

Table S1. Concentrations (average \pm standard deviation, $\mathrm{n}=2$ ) of major, minor and trace elements (in $\mathrm{mg} \mathrm{kg}^{-1}$, unless otherwise indicated) determined for the reference material LKSD-3 (CANMET) and the in-house standard DST6 (Acme Analytical Laboratories) by ICP-MS

\begin{tabular}{|c|c|c|c|c|c|c|c|}
\hline & Reference value & Our value & Recovery / (\%) & & Reference value & Our value & Recovery / $(\%)$ \\
\hline $\mathrm{Li}$ & $25 \pm 2$ & $28.8 \pm 1.2$ & 115.2 & As & $27 \pm 2$ & $22.9 \pm 0.8$ & 84.8 \\
\hline $\mathrm{Be}^{*}$ & 3.3 & $3.0 \pm 0.0$ & 90.9 & $\mathrm{Rb}$ & $78 \pm 10$ & $77.6 \pm 0.8$ & 99.5 \\
\hline $\mathrm{Na}(\%)$ & $1.72 \pm 0.07$ & $1.75 \pm 0.00$ & 101.7 & $\mathrm{Sr}$ & $240 \pm 42$ & $272 \pm 3$ & 113.3 \\
\hline $\operatorname{Mg}(\%)$ & $1.20 \pm 0.06$ & $1.14 \pm 0.07$ & 95.0 & $\mathrm{Y}$ & $30 \pm 10$ & $26.6 \pm 0.1$ & 88.7 \\
\hline $\mathrm{Al}(\%)$ & $6.61 \pm 0.21$ & $6.55 \pm 0.27$ & 99.1 & $\mathrm{Zr}^{*}$ & 50.1 & $62.2 \pm 1.2$ & 124.2 \\
\hline $\mathrm{P}$ & $1090 \pm 40$ & $1146 \pm 8$ & 105.1 & $\mathrm{Nb}^{*}$ & 8.11 & $9.16 \pm 0.11$ & 112.9 \\
\hline $\mathrm{S}(\%)$ & $0.14 \pm 0.03$ & $0.17 \pm 0.01$ & 121.4 & $\mathrm{Mo}^{*}$ & 12.70 & $12.8 \pm 0.1$ & 100.8 \\
\hline $\mathrm{K}(\%)$ & $1.84 \pm 0.07$ & $1.66 \pm 0.02$ & 90.2 & $\mathrm{Ag}$ & $2.7 \pm 0.11$ & $2.67 \pm 18$ & 98.9 \\
\hline $\mathrm{Ca}(\%)$ & $1.64 \pm 0.14$ & $1.77 \pm 0.01$ & 107.9 & $\mathrm{Cd}^{*}$ & 5.60 & $5.66 \pm 0.01$ & 101.1 \\
\hline $\mathrm{Sc}$ & $13 \pm 2$ & $12.6 \pm 0.5$ & 96.9 & Sn & $3 \pm 2$ & $2.1 \pm 0.0$ & 70.0 \\
\hline $\mathrm{Ti}$ & $3330 \pm 330$ & $3195 \pm 21$ & 95.9 & $\mathrm{Sb}$ & $1.3 \pm 0.1$ & $1.27 \pm 0.01$ & 97.7 \\
\hline V & $82 \pm 8$ & $84.1 \pm 1.6$ & 102.6 & Cs & $2.3 \pm 0.3$ & $2.6 \pm 0.1$ & 113.0 \\
\hline $\mathrm{Cr}$ & $87 \pm 8$ & $76.5 \pm 0.7$ & 87.9 & Hf & $4.8 \pm 0.7$ & $3.6 \pm 0.1$ & 75.0 \\
\hline $\mathrm{Mn}$ & $1440 \pm 80$ & $1472 \pm 4$ & 102.2 & $\mathrm{Ta}$ & $0.7 \pm 0.1$ & $0.96 \pm 0.10$ & 137.1 \\
\hline $\mathrm{Fe}(\%)$ & $4.0 \pm 0.2$ & $4.21 \pm 0.02$ & 105.3 & $\mathrm{~Pb}$ & $29 \pm 3$ & $33.7 \pm 1.3$ & 116.2 \\
\hline Co & $30 \pm 2$ & $32.6 \pm 0.3$ & 108.7 & $\mathrm{Bi}^{*}$ & 4.70 & $4.86 \pm 0.07$ & 103.4 \\
\hline $\mathrm{Ni}$ & $47 \pm 5$ & $49.4 \pm 2$ & 105.1 & $\mathrm{Th}$ & $11.4 \pm 0.7$ & $11.6 \pm 0.0$ & 101.8 \\
\hline $\mathrm{Cu}$ & $35 \pm 3$ & $38.1 \pm 0.0$ & 108.9 & $\mathrm{U}$ & $4.6 \pm 0.5$ & $4.6 \pm 0.0$ & 100.0 \\
\hline $\mathrm{Zn}$ & $152 \pm 14$ & $167 \pm 1.5$ & 109.9 & & & & \\
\hline $\mathrm{Ga}$ & $17 \pm 4$ & $16.85 \pm 0.03$ & 99.1 & & & & \\
\hline
\end{tabular}

*DST6 (in-house standard). 
Table S2. Correlation coefficients calculated for concentrations of select elements, grain-size and LOI $\left(550{ }^{\circ} \mathrm{C}\right)$ in a sediment core from the Morrão River $(\mathrm{n}=32$, entire data). Marked correlations are significant at $\mathrm{p}<0.05$

\begin{tabular}{|c|c|c|c|c|c|c|c|c|c|c|c|c|c|c|c|c|}
\hline & $\mathrm{Li}$ & $\mathrm{Na}$ & $\mathrm{Mg}$ & $\mathrm{Al}$ & $S$ & $\mathrm{~K}$ & $\mathrm{Ti}$ & $\mathrm{V}$ & As & $\mathrm{Rb}$ & Mo & Cs & Silt & Clay & Sand & LOI \\
\hline $\mathrm{Li}$ & 1.00 & & & & & & & & & & & & & & & \\
\hline $\mathrm{Na}$ & -0.20 & 1.00 & & & & & & & & & & & & & & \\
\hline $\mathrm{Mg}$ & 0.06 & 0.62 & 1.00 & & & & & & & & & & & & & \\
\hline $\mathrm{Al}$ & 0.96 & -0.09 & 0.13 & 1.00 & & & & & & & & & & & & \\
\hline $\mathrm{S}$ & 0.45 & 0.35 & 0.33 & 0.51 & 1.00 & & & & & & & & & & & \\
\hline K & 0.93 & -0.20 & 0.11 & 0.90 & 0.40 & 1.00 & & & & & & & & & & \\
\hline $\mathrm{Ti}$ & 0.91 & -0.26 & 0.06 & 0.89 & 0.29 & 0.86 & 1.00 & & & & & & & & & \\
\hline V & 0.59 & -0.21 & 0.24 & 0.61 & 0.11 & 0.64 & 0.53 & 1.00 & & & & & & & & \\
\hline As & 0.38 & 0.19 & 0.33 & 0.41 & 0.75 & 0.36 & 0.24 & 0.23 & 1.00 & & & & & & & \\
\hline $\mathrm{Rb}$ & 0.78 & -0.31 & -0.03 & 0.73 & 0.21 & 0.88 & 0.72 & 0.66 & 0.16 & 1.00 & & & & & & \\
\hline Мo & 0.31 & 0.16 & 0.06 & 0.31 & 0.76 & 0.24 & 0.04 & -0.03 & 0.63 & 0.14 & 1.00 & & & & & \\
\hline Cs & 0.80 & 0.09 & 0.17 & 0.86 & 0.65 & 0.77 & 0.58 & 0.54 & 0.53 & 0.64 & 0.58 & 1.00 & & & & \\
\hline Silt & 0.06 & 0.16 & -0.28 & 0.15 & -0.01 & -0.06 & -0.06 & -0.09 & -0.36 & -0.14 & 0.09 & 0.22 & 1.00 & & & \\
\hline Clay & -0.51 & 0.05 & -0.51 & -0.47 & -0.51 & -0.64 & -0.52 & -0.46 & -0.55 & -0.59 & -0.28 & -0.42 & 0.62 & 1.00 & & \\
\hline Sand & 0.02 & -0.15 & 0.32 & -0.07 & 0.08 & 0.14 & 0.13 & 0.15 & 0.40 & 0.21 & -0.05 & -0.14 & -0.99 & -0.70 & 1.00 & \\
\hline LOI & -0.08 & 0.49 & 0.59 & 0.00 & 0.38 & 0.01 & -0.12 & -0.01 & 0.35 & -0.01 & 0.27 & 0.13 & -0.32 & -0.34 & 0.34 & 1.00 \\
\hline
\end{tabular}

Table S3. Correlation coefficients calculated for concentrations of elements associated with the phosphorous or iron in the 0-90 $\mathrm{cm}$ depth in a sediment core from the Morrão River $(\mathrm{n}=15)$. Marked correlations are significant at $\mathrm{p}<0.05$

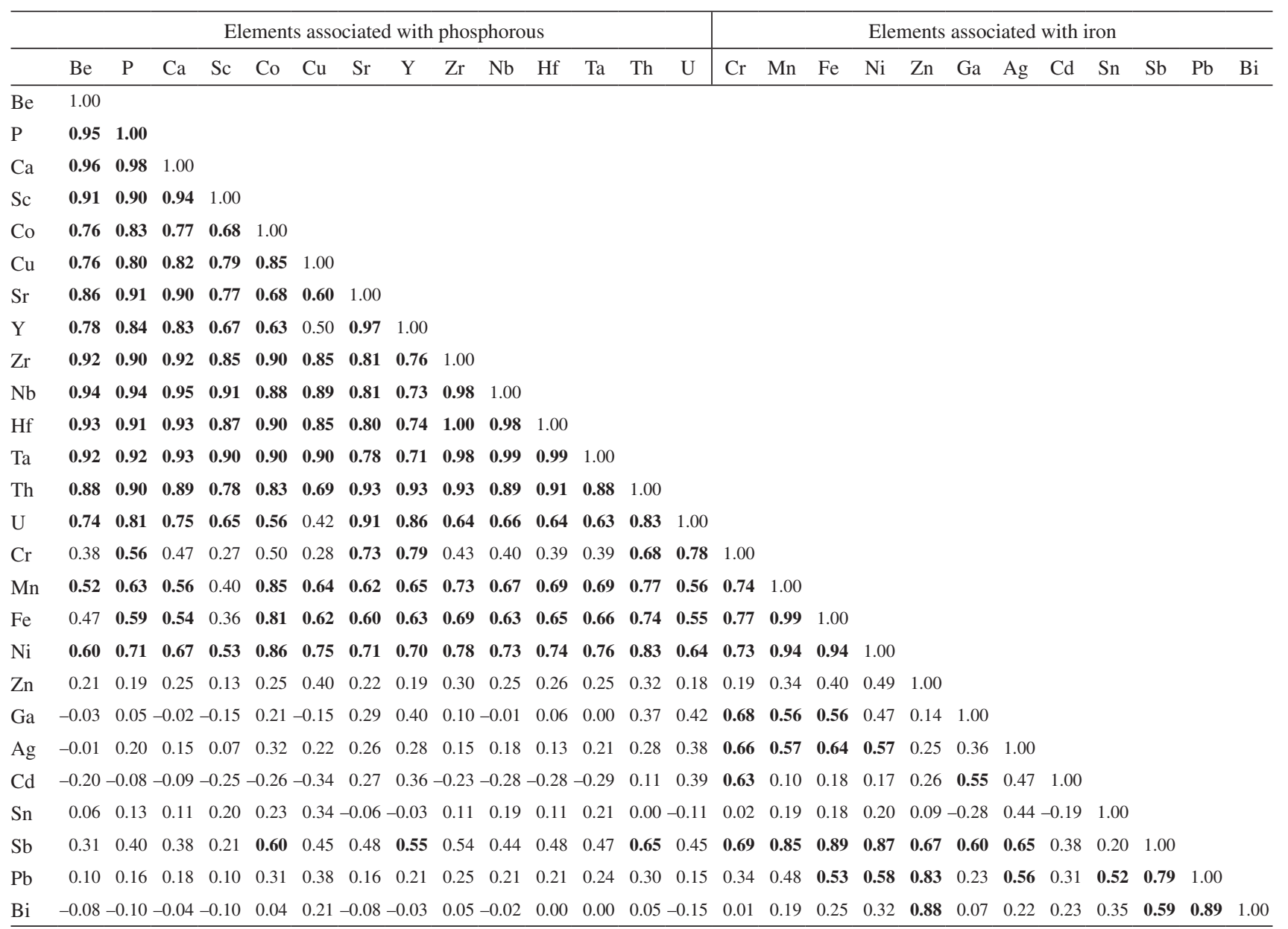

